\title{
THE POTENTIAL FOR DEVELOPMENT OF NON-AGRICULTURAL ACTIVITIES IN RURAL AREAS OF NORTHWEST POLAND
}

\author{
Ewa Kiryluk-Dryjska ${ }^{\natural}$, Patrycja Beba $^{1}$ \\ ${ }^{1}$ Poznań University of Life Sciences, Poland
}

\begin{abstract}
The objective of this study was to assess the potential for growth of non-agricultural rural activities in northwest Poland. The analysis was performed within a linear regression framework. The results demonstrated that non-agricultural activities were determined by entrepreneurship, infrastructure and small size of farms. The estimated potential of nonagricultural activities was highest in Zachodniopomorskie voivodeship, moderate in Wielkopolskie voivodeship, and lowest in Lubuskie voivodeship. The results also suggest that in order to fully tap into the potential of non-agricultural activities, some institutional support needs to be provided by the local government.
\end{abstract}

Keywords: non-agricultural activities, income diversification, rural areas

\section{INTRODUCTION}

Non-agricultural activity can be defined as any activity taken by individual farm members which is not directly related to agricultural production. Examples cited by Kołodziejczyk (2004) include tourism, food processing, renewable energy production, services delivered with the use of farm equipment, handcraft and aquaculture.

Non-agricultural activity is considered as the key driver of multifunctional and sustainable rural development. Because labor is oversupplied in Polish agriculture, diversification of activities becomes one of the main objectives of rural development strategies. It provides alternative sources of income, improves the rural population's quality of life, reduces unemployment, stimulates the outflow of workforce from agriculture and increases farming profitability. This is especially important for farms located in less-favored areas.

Since the Agenda 2000 reform, the need for diversification of agricultural activities has been addressed by the EU. Non-agricultural activities are believed to prevent marginalization and depopulation of rural areas. In Poland, support for non-agricultural activities is mainly provided under rural development programs co-financed by the EU. Since 2004, a total of PLN 1.5 billion has been delivered.

According to the recent Polish Agricultural Census, in 2010 there were 2146 thousands farms, including ca. $16 \%$ engaged in non-agricultural activities. Krakowiak-Bal (2010) highlighted the growing interest in non-agricultural activities among Polish farmers. However, as Bański (2006) states, the percentage of farms with an additional source of income continues to be low.

Previous studies of non-agricultural activities in Poland resulted in identifying social, economic and technical factors behind the expansion of non-agricultural activities (Bański, 2004). An unfavorable age structure, along with low levels of education, remains one of the social barriers to the development of non-agricultural activities. Also, advanced age and lack of skills reduce

$\bowtie$ PhD hab. Ewa Kiryluk-Dryjska, Department of Economics and Economic Policy in Agribusiness, Poznań University of Life Sciences, 28 Wojska Polskiego St., 60-637 Poznań, Poland, e-mail: kiryluk-dryjska@up.poznan.pl, https://orcid.org/ 0000-0003-4353-8196 
the willingness to start new activities. Economic factors affecting the development of non-agricultural activities, as cited by Bański (2004), include the unemployment rate, financial condition of farms, employment structure and level of public support, whereas infrastructure remains the key technical factor. Kłodziński (2010) noticed that the lack of entrepreneurship among rural inhabitants and their inability to interpret legal regulations applicable to sources of support should also be considered as barriers to non-agricultural activity. According to Bański (2006) and Pałka (2010), factors stimulating non-agricultural activities include the proximity of a metropolis and attractiveness to tourists.

In order to support and stimulate non-agricultural activities, it is important to assess their development potential. This paper attempts to do so with the use of a multiple linear regression model, using the example of the northwest region of Poland.

\section{METHOD}

A regression model was constructed for rural and urbanrural municipalities located in Zachodniopomorskie, Wielkopolskie and Lubuskie voivodeships which make up the northwest region of Poland. The main features of rural areas in the northwest region were defined based on results provided by Beba and Kiryluk-Dryjska (2016). Using the factor analysis, the authors identified eight main characteristics of rural areas in the region considered: infrastructure, intensive agricultural production, organic production, entrepreneurship, natural conditions for agricultural production, animal production and demography ${ }^{1}$. Each comprises a set of simple variables calculated based on statistical data ${ }^{2}$. In this paper, component variables of each factor were used to calculate synthetic coefficients in accordance with the method by Wysocki $(2010)^{3}$.

Next, the synthetic coefficients were tested to develop a multiple regression model for the dependent variable defined as the percentage of farms engaged in

${ }^{1}$ The factor analysis was conducted for 53 simple variables describing agricultural potential and rural development levels based on data from the Central Statistical Office.

${ }^{2}$ The list of all component variables of the factors are presented in the paper by Beba and Kiryluk-Dryjska (2016).

${ }^{3}$ Correlated variables (with a correlation coefficient above $0.5)$ were eliminated. non-agricultural activities. A forward stepwise selection method was used to select the relevant predictors. This method builds a model by successively adding variables, starting with the one most correlated with the dependent variable. The significance of each variable is determined based on the Snedecor's F-test. Once all variables with significant impact on the dependent variable are added, the process of building the model is completed (Stanisz, 2007). The model was then used to assess the potential of non-agricultural activities in the northwest region of Poland. The discussion on the possible institutional support for non-agricultural activities was based on noncooperative game theory.

\section{RESULTS}

The regression analysis with eight independent variables (synthetic coefficients of rural development in the region considered) found the constant term to be insignificant. Therefore, forward stepwise regression was performed under the assumption of a zero constant term. The building steps of the model are presented in Table 1 .

Non-agricultural activities demonstrate high correlation with the small size index. This variable alone explains $84.9 \%$ of variance in non-agricultural activities. The entrepreneurship index increases the amount of variation explained by 6.1 percentage points. The remaining variables (infrastructure and intensive agricultural production) have only a slight, though statistically significant, impact on non-agricultural activities. The results show no link between non-agricultural rural activities and other independent variables covered by the analysis, including demography, organic agriculture, natural conditions for agricultural production and animal production. Table 2 shows the regression coefficients together with a statistical description of the model.

The regression equation is as follows:

$$
\begin{gathered}
Y=16.1 \cdot x_{1}+45.3 \cdot x_{2}-7.3 \cdot x_{3}-3.26 \cdot x_{4} \\
R=0.95\left(R^{2}=0.91\right)
\end{gathered}
$$

with:

$Y$ - Percent of farms engaged in non-agricultural activities

$x_{1}$ - Small size index

$x_{2}-$ Entrepreneurship index

$x_{3}-$ Infrastructure index

$x_{4}-$ Intensive agricultural production index. 
Table 1. Selection of variables significantly affecting non-agricultural activities with the use of forward stepwise linear regression

\begin{tabular}{lcccrrrr}
\hline \multirow{2}{*}{$\begin{array}{c}\text { Synthetic coefficient } \\
\text { (independent variable) }\end{array}$} & step & $\begin{array}{c}\text { Spearman } \\
\text { coefficient }\end{array}$ & $\mathrm{R}^{2}$ & change in $\mathrm{R}^{2}$ & $\mathrm{~F}$ & $\mathrm{p}$ \\
\cline { 2 - 7 } & 1 & 0.92 & 0.85 & 0.850 & 1752.12 & 0.00 \\
Small size index & 2 & 0.95 & 0.91 & 0.061 & 210.16 & 0.00 \\
Entrepreneurship index & 3 & 0.96 & 0.91 & 0.002 & 8.32 & 0.00 \\
Infrastructure index & 4 & 0.96 & 0.91 & 0.001 & 4.09 & 0.04 \\
Intensive agricultural production index & 4 & & & & & \\
\hline
\end{tabular}

Source: own calculation.

Table 2. Multiple regression results; dependent variable (y): percentage of farms engaged in non-agricultural activities

\begin{tabular}{lccccc}
\hline & \multicolumn{5}{c}{$\begin{array}{c}\mathrm{R}=0.96 \\
\text { Synthetic coefficient } \\
\text { Standard error of the estimate 4.52 }\end{array}$} \\
\cline { 2 - 6 } \multicolumn{1}{c}{ (independent variable) } & $\mathrm{R}^{*}$ & $\begin{array}{c}\text { Standard } \\
\text { deviation of } \mathrm{b}^{*}\end{array}$ & $\mathrm{~B}$ & $\begin{array}{c}\text { Standard } \\
\text { deviation of } \mathrm{b}\end{array}$ & $\mathrm{p}$ \\
\hline Small size index & 0.68 & 0.05 & 16.09 & 1.14 & 0.00 \\
Entrepreneurship index & 0.47 & 0.04 & 45.33 & 3.51 & 0.00 \\
Infrastructure index & -0.10 & 0.04 & -7.32 & 2.86 & 0.01 \\
Intensive agricultural production index & -0.08 & 0.04 & -3.26 & 1.64 & 0.04 \\
\hline
\end{tabular}

Source: own calculation.

The model explains $91 \%$ of variance in the group of farms engaged in non-agricultural activities. It demonstrates that the index of non-agricultural activity is higher in areas where small farms predominate and indexes of entrepreneurship are high; and is lower in municipalities with a well-developed infrastructure and intensive agriculture. The regression model was used to predict the potential for development of non-agricultural activities in the northwest region of Poland (Table 3).

The predicted potential of non-agricultural activities in the Northwest region was estimated at $17.2 \%$, reaching the same level for Wielkopolskie voivodeship. The value calculated for Lubuskie voivodeship (15.7\%) was below the macroregion's average. The results of the model show that, compared to other regions, Lubuskie voivodeship offers less development opportunities for non-agricultural activities. In Zachodniopomorskie voivodeship, the potential of non-agricultural
Table 3. Predicted potential for development of non-agricultural activities in the northwest region $(\%)$

\begin{tabular}{lcccc}
\hline Indicator & $\begin{array}{c}\text { Macro- } \\
\text { region }\end{array}$ & $\begin{array}{c}\text { Wielkopol- } \\
\text { skie }\end{array}$ & Lubuskie & $\begin{array}{c}\text { Zachodnio- } \\
\text { pomorskie }\end{array}$ \\
\hline Potential & 17.2 & 17.2 & 15.7 & 18.2 \\
Share & 100.0 & 100.0 & 91.2 & 106.1 \\
\hline
\end{tabular}

Source: own calculation.

development reaches $18.2 \%$, which is $6 \%$ above the level calculated for the macroregion as a whole.

The results of the model can be verified by comparing them with the actual indexes of non-agricultural activity calculated for the regions under consideration based on data delivered by the Central Statistical Office (Table 4). These figures are within standard error of the 
Table 4. Actual indexes of non-agricultural activity in northwest Poland in $2010(\%)$

\begin{tabular}{lcccc}
\hline Indicator & $\begin{array}{c}\text { Macro- } \\
\text { region }\end{array}$ & $\begin{array}{c}\text { Wielkopol- } \\
\text { skie }\end{array}$ & Lubuskie & $\begin{array}{c}\text { Zachodnio- } \\
\text { pomorskie }\end{array}$ \\
\hline $\begin{array}{l}\text { Activity } \\
\text { index }\end{array}$ & 16.5 & 16.5 & 15.0 & 17.6 \\
Share & 100.0 & 100.0 & 90.8 & 107.0 \\
\hline
\end{tabular}

Source: own calculation.

estimate of model results. Moreover, percentage differences between voivodeships are consistent with the predicted potential indexes (Table 3).

The presented model can be used to estimate the potential of non-agricultural activities of particular administrative units in the region considered. It could also be applied in practice to strengthen the support for nonagricultural rural activities.

Because engaging in non-agricultural activities is costly and risky, small farmers are often reluctant to do so without institutional support. While support measures could boost non-agricultural activities and the local economy, they represent a $\operatorname{cost}^{4}$ from the local governments' standpoint. Thus, local decision-makers must consider whether to provide some institutional support for non-agricultural activities or just let the farmers deal with this issue. This above is a strategic problem that can be presented within the framework of game theory as a $2 \times 2$ game with two players (small farmers and local governments) guided by two strategies. Farmers can either engage or not in non-agricultural activities, while local governments can provide support or abstain from supporting them.

Clearly, the best option for local governments is the one where farmers engage in non-agricultural activities without any additional support. The second best option would be to provide them with support as an incentive to start an activity. Providing additional support without any result would be the worst option for the municipalities, as it would simply mean a waste of resources.

\footnotetext{
${ }^{4}$ By institutional support we mean any form of incentive for the farmers to start an activity. It might involve some financial benefits as well as information, training, advisory services and assistance in applying for EU funds.
}

The best option for small farmers would be to set up an enterprise with additional support from the local government. However, without support, they would not be willing to do so. The order of players' preferences is as shown in Table $5^{5}$.

Table 5. Payoff matrix of the game between small farmers and the local government on the support for non-agricultural activities

\begin{tabular}{lcc}
\hline \multirow{1}{*}{ Small farmers } & \multicolumn{2}{c}{ Local governments } \\
\cline { 2 - 3 } & support & do not support \\
\hline $\begin{array}{l}\text { Start a non-agricultural } \\
\text { activity }\end{array}$ & $4,3^{\mathrm{B}}$ & 1,4 \\
Status quo & 2,1 & $3,2^{*}$ \\
\hline
\end{tabular}

* Nash equilibrium.

в Brams "nonmyopic" equilibrium.

Source: own calculation.

The standard game theory provides for a unique Nash equilibrium payoff (state 3,2 ) which is the outcome of the local governments' dominant strategy of "not supporting non-agricultural activities." The small farmers' best response to this strategy is not to set up an enterprise. This rather pessimistic outcome explains the prevailing situation in areas where the potential behind non-agricultural activities is not fully tapped into. However, if the players are allowed to look a few steps ahead before deciding on their next move, the conflict may be analyzed with the use of an alternative branch of game theory referred to as the "theory of moves" (TOM) ${ }^{6}$. The equilibrium predicted with the use of TOM is the state $(4,3)$. The path towards this state is explained by the concept introduced by Brams (1994) called the "twosidedness convention": "two-sidedness convention describes the conditions under which one player will be magnanimous by moving from a state, even though this move leads to an outcome with worse payoff for that player." In this case, the local government, being aware

\footnotetext{
${ }^{5}$ Ordinal preferences are used; 4 stands for the players' best option, 1 for the worst.

${ }^{6}$ TOM was introduced by Brams (1994). It combines an extensive form and a normal form of the classical game theory. A game is played on a payoff matrix, like a normal-form game. The players, however, can move (by switching their strategies) from one outcome in a payoff matrix to another, so the sequential moves of an extensive form game are built into the normal form.
} 
that the potential behind non-agricultural activities is wasted, can shift to the "support" strategy and thus induce a Pareto-superior outcome of the game (state 4,3). In practice, the results of the game suggest that institutional support from the local government is needed in order to fully exploit the potential of non-agricultural activities.

\section{CONCLUSIONS}

The constructed regression model demonstrates that the index of non-agricultural activities depends on four main factors: small size of farms, entrepreneurship, infrastructure and intensive agricultural production. The selection of model variables seems to be consistent with previous studies. Bański (2004), Krakowiak-Bal (2010) and Czarnota (2013) previously demonstrated that nonagricultural activities were undertaken mainly by small farms which probably do not generate enough income from agricultural production. Naturally, small farmers dealing with unfavorable economic conditions are more willing to search for alternative sources of income.

A positive correlation between non-agricultural activities and entrepreneurship was identified by Kłodziński (2010) and Bański (2006). In the context of a literature study (Bański, 2004), the negative correlation between the index of non-agricultural activities and the level of infrastructure seems questionable. The results indicate that agricultural income tends to be diversified mostly in areas with underdeveloped infrastructure. In this case, the interpretation of the model results is not straightforward, as this relationship may be due to the fact that areas predominantly populated by small farms also tend to demonstrate poor infrastructural development.

The results of the predicted potential for non-agricultural activities in the northwest macroregion show that it reaches the highest levels in Zachodniopomorskie voivodeship, moderate in Wielkopolskie voivodeship, and the lowest Lubuskie voivodeship. The figures provided by the model are close to actual indexes of non-agricultural activities calculated based on statistical data. This demonstrates that the variables were adequately selected for the model, and the model reflects the actual potential for the development of non-agricultural activities in the region concerned.

The model can be used to estimate the potential of non-agricultural activities of the region's different administrative units (municipalities, districts, voivodeships). The results of the model can be practically applied to target or intensify support for non-agricultural rural activities. Moreover, the results of the strategic conflict discussed suggest that institutional support from local government is needed to fully exploit the potential of non-agricultural activities.

Although the model was built for the northwest macroregion of Poland, the proposed method may be used for other regions or on a countrywide basis.

\section{SOURCE OF FINANCING}

This work was supported by the Polish National Science Center, grant number 2013/11/B/HS4/00685.

\section{REFERENCES}

Bański, J. (2004). Możliwości rozwoju alternatywnych źródeł dochodu na obszarach wiejskich [Possibility of Development of Alternative Income Sources in Rural Areas]. In: E. Pałka (Ed.), Pozarolnicza działalność gospodarcza na obszarach wiejskich. Warszawa: Zakład graficzny UW [in Polish].

Bański, J. (2006). Geografia polskiej wsi [Geography of Polish rural areas]. Warszawa: PWE [in Polish].

Beba, P., Kiryluk-Dryjska, E. (2016). Identyfikacja barier rozwoju wsi i rolnictwa w Polsce na przykładzie regionu północno-zachodniego [Identification of rural development obstacles in Poland on the example of north-western region]. Pr. Nauk. Uniw. Ekon. Wroc., Gospodarka regionalna w teorii i praktyce, 433, 29-39 [in Polish].

Biernat-Jarka, A. (2004). Działalność pozarolnicza jako jedno ze źródeł dochodów wiejskich gospodarstw domowych związanych $\mathrm{z}$ rolnictwem [Non-agricultural activities as one of the income source of agricultural households]. In: M. Adamowicz (Ed.), Wiejskie gospodarstwa domowe w obliczu problemów transformacji, integracji i globalizacji. Warszawa: Wyd. SGGW [in Polish].

Brams, S. (1994). Theory of Moves. Cambridge University Press.

Czarnota, P. (2013). Struktura działalności pozarolniczej w towarowych gospodarstwach rolnych w Polsce [Structure of oga in agricultural holdings in Poland]. Rocz. Nauk. SERiA, 15(3), 51-56 [in Polish].

GUS (2016). Bank Danych Lokalnych Głównego Urzędu Statystycznego. Retrieved from: https://bdl.stat.gov.pl/

Kłodziński, M. (2010). Główne funkcje polskich obszarów wiejskich z uwzględnieniem dezagraryzacji wsi i pozarolniczej działalności gospodarczej [Major trends in the 
Polish rural areas including deagrarisation and the rise of non-agricultural business activities]. Stud. BAS, 4(24), 9-28 [in Polish].

Kołodziejczyk, D. (2004). Pozarolnicza działalność gospodarcza w indywidualnych gospodarstwach rolnych w skali gmin [Non-agricultural economic activities in private farming on the local scale]. In: E. Pałka (Ed.), Pozarolnicza działalność gospodarcza na obszarach wiejskich. Studia Obszarów Wiejskich IGiPZ PAN (v. 5, p. 23-33). Warszawa: Zakład Graficzny UW [in Polish].

Krakowiak-Bal, A. (2010). Rozwój dodatkowej działalności gospodarczej w gospodarstwach z krajów UE [Other gainful activity in agricultural holdings in Poland and EU countries]. Infr. Ekol. Teren. Wiej., 5, 209-217 [in Polish].
Pałka, E. (2010). Kierunki rozwoju pozarolniczej działalności na obszarach wiejskich w Polsce [The directions of development of non-agricultural economic activities in rural areas in Poland]. Infr. Ekol. Teren. Wiej., 1, 163-174 [in Polish].

Stanisz, A. (2007). Przystępny kurs statystyki z zastosowaniem STATISTICA PL na przykładach z medycyny [Statistica course with the use of STATISTICA PL at medical examples]. Tom 3. Analizy wielowymiarowe. Kraków: StatSoft Polska [in Polish].

Wysocki, F. (2010). Metody taksonomiczne w rozpoznawaniu typów ekonomicznych rolnictwa i obszarów wiejskich [Taxonomic methods in economic typology of agriculture and rural areas]. Poznań: Wyd. UP [in Polish]. 